\title{
Atomic agency launches bid to bank nuclear fuel
}

\section{LONDON}

Mohamed ElBaradei, director-general of the International Atomic Energy Agency (IAEA), has taken a step towards persuading countries to relinquish control of their nuclear fuel.

On 7 November, ElBaradei announced that the United States and Russia have agreed to contribute to an international fuel bank. The move paves the way for the first stage in a programme to bring the entire nuclear-fuel cycle under multilateral control, says ElBaradei, who, along with his agency, won this year's Nobel Peace Prize. In theory, the bank will help dissuade nuclearhungry nations from developing facilities to enrich uranium.

Enrichment technology can also be used to develop weapons-grade material and is at the heart of current tensions between the IAEA and Iran.

Under the fuel-bank programme, nations that meet certain security standards, such as observing non-proliferation treaties, would be guaranteed a supply of fuel. Non-proliferation experts are applauding the idea of the bank, but caution that ElBaradei's long-term aims are unrealistic in today's political environment.

So far, the United States has said it will supply more than 17 tonnes of highly enriched uranium, taken from dismantled nuclear weapons. This will be 'downblended' to create reactor fuel. Russia has not said how much it will contribute.
The bank is meant to build confidence in nuclear security, says Geoff Shaw, policy adviser to ElBaradei at the IAEA's Geneva headquarters. If IAEA members can agree to the creation of the bank - perhaps when the agency's governors meet next March - they could be open to considering further parts of ElBaradeis nonproliferation plans, Shaw adds.

But such ambitions are not easy to realize. ElBaradei's second proposal is a moratorium on the development of technology for uranium enrichment and reprocessing, which can be used to recycle nuclear fuel and create weapons-grade material. Nations with this ability, such as the United States, Russia, France and Britain, would be allowed to retain it. But others would agree
op it in the next ten years, despite the fact that non-proliferation agreements allow them to do so for civilian purposes.

Sceptics point out that there are few incentives to sign up to the moratorium. "Are we going to say to other countries that they have to forgo their right to develop the fuel cycle?" asks Lawrence Scheinman, a nuclear-policy expert at the Monterey Institute of International Studies in Washington DC, and an adviser to three former US governments.

There are a number of reasons why nations might reject the moratorium, he says. Uranium suppliers such as Australia and Canada might find it profitable to enrich fuel before

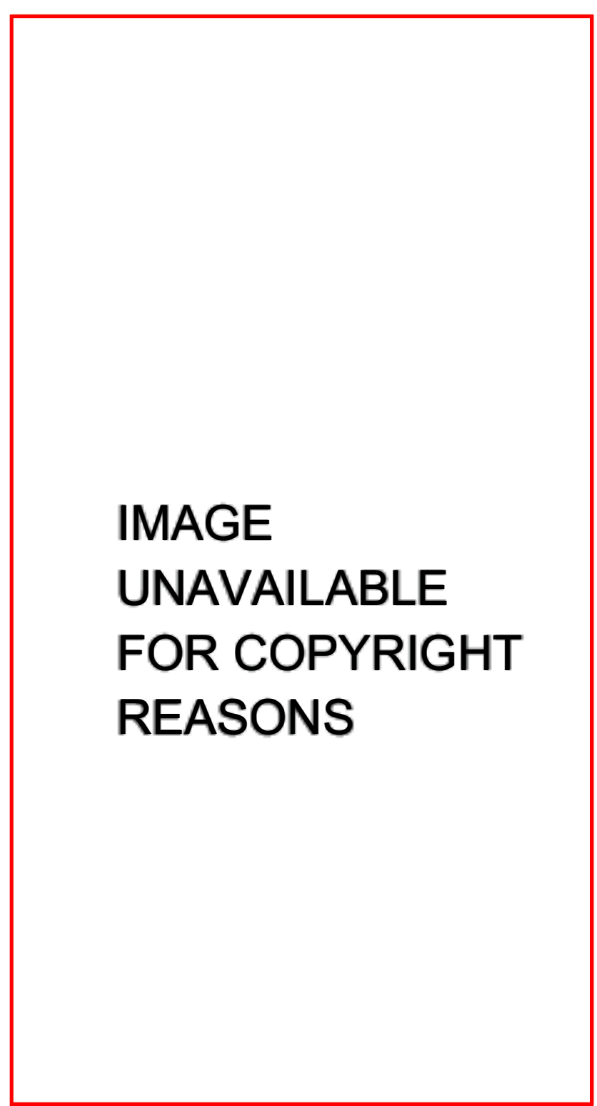

Mohamed ElBaradei wants to see the whole of the nuclear-fuel cycle under multilateral control.

selling it, for example. Other countries will want fuel-cycle capability so that they can at least keep the option of developing weapons. What would make Iran join the scheme, asks Mark Fitzpatrick, a non-proliferation expert at the Institute for International Strategic Studies in London. ${ }^{\alpha}$ They want enrichment for their

\section{Scheme to track greenhouse gases takes to the air}

\section{TOKYO}

Passenger planes in Japan are being pressed into service tomonitor greenhouse-gas levels in the atmosphere. On 5 Nowember, Japan Airlines flew its first plane equipped with a device that continuously measures atmospheric car bon dioxide.

Targeting flight paths from Tolyo to southeastand east Asia and to Europe, researchers say that the measurements collected by the project will provide much-needed

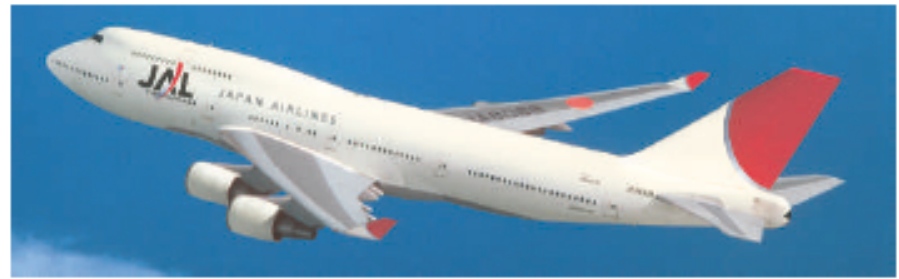

Plane sailing: Japan Airlines plans to provide continuous data on $\mathrm{CO}_{2}$ levels.

information about $\mathrm{CO}_{2}$ emissions over Asia. Eventually five planes will carry the equipmenton routine flights, measuring $\mathrm{CO}_{2}$ from the moment they take off to when they land. As they criss-cross the region, they will build up a fuller threedimensional picture of $\mathrm{CO}_{2}$ than can be obtained by ground-based or satellite observations, researchers say.

"We were looking for a way to observe carbon dioxide continuously, in broadareas and ata low cost," says Toshinobu Machida, an atmospheric researcher at the National Institute for Environmental Studies in Tsukuba, Japan. To get the project up and running the Japanese government has provided $¥ 80$ million (US\$670,000) per year since 2003. Running costsfrom nextyear 
nudear weapons programme," he alleges.

But if the second stage of ElBaradeis plan is tough, the third and fourth are truly ambitious. Part three would bring the reprocessing of spent fuel under multilateral control, perhaps at a series of dedicated regional facilities. Finally, existing enrichment facilities would come under international ownership. Countries that rely on such facilities to fuel their nuclear arsenals are extremely unlikely to agree, say experts. "For the United States, that's a dream," says Fitzpatrick.

He acknowledges that the fuel bank, if it can be made to work, would be a useful step towards achieving at least some of ElBaradei's plans. But even supporters accept that there is a very long diplomatic fight to come. "No one is naive on this point," says Shaw. "The longer term will be much more difficult."

Jim Giles

\section{are expected to be half that}

The latest project follows on froma similar idea in the $1990 \mathrm{~s}$. In 1993, two planes run by Japan Airlines begancarrying simple equipment to collectairsamples for analysisin the laboratory. Butsamples were takenonly twice a month on flights between Tokyo and Australia. When the planes came up for retirement, scientists began to developa device that could offer continuous monitoring. The equipment samples air from the front of the plane's engines and so does not pick up the aircraft's own emissions, says Yukio Nakagawa, manager at the engineering department of Japan Airlines. The hardest task, he notes, was creating a device with the appropriate specifications given the limited time and cost.

Inside the plane's cargo compartment, air flows through spectrometers that continuously measure the $\mathrm{CO}_{2}$ concentration. Associated equipment detects other greenhouse gases, such as sulphur hex afluoride.

Although the equipmenthas so far flown onjust one plane, the company plans to add devices to four more of its Boeings by the end of nextyear.

Toshihiro Ogawa, a retired atmospheric chemist formerly at the University of Tokyo, says the project should help researchers to quantify carbon dioxide emissions and so make it easier for countries to conform to the Kyoto Protocol on climate change. "Figuring out the real carbon dioxide emissions per country is our big homework," he says. Ichiko Fuyuno
ON THE RECORD

CII'd like to say to the good citizens of Dover: if there is a disaster in your area, don't turn to God. You just rejected him from your city."

Christian talk-show host Pat Robertson attacks the result of the school-board election in Dover, Pennsylvania, which saw eight proponents of intelligent design lose their seats (see page 267).

\section{cEven if a dynamic physics model suggests cow tipping is possible, the biology ultimately gets in the way." \\ Margo Lillie of the University of British Columbia argues that, contrary to popular belief, it is far from easy to tip over acow.}

Sources: Reuters, The Times

\section{SCORECARD}

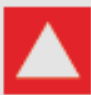
Music Astronauts on the International Space

Station get an unusual wake-up call as Paul McCartney becomes the first person to broadcast live music into space.

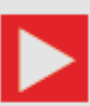
Espionage ARussian researcher claims to have found a way to control tur tles remotely. The creatures can be used to spy behind enemy lines and even deliver bombs, hesays.

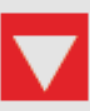
Lunar land prospecting Chinese authorities have shutdown a "Lunar Embassy't that sold plots on the Moonfor US\$37 an acre.

\section{OVERHYPED}

Treatments for bird flu The threat of anavian flu pandemic has worriedmany people. As a result, a number of unconventional remedies are being offered as ways to combat the disease. In recent weeks, oil of oregano, colloidal silver and the pickled Koreancabbage known as kimchi have all been touted for their purported flu-fighting properties. None has been proved to work - and none can beat the advice of the experts in the event of a pandemic just stay at home.

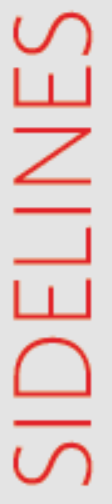

